\title{
Validity of CAPM by Using Portfolios: Evidence from Indian Capital Market
}

\author{
K.M. Yaseer $^{1} \&$ K.P. Shaji ${ }^{2}$ \\ ${ }^{1}$ Department of Commerce, PG Department of Commerce Govt. College Madapally, University of Calicut, India \\ ${ }^{2}$ Urban and Rural Development Finance Corporation, Thiruvananthapuram, India
}

Correspondence: K.M. Yaseer, Department of Commerce, PG Department of Commerce Govt. College Madapally, University of Calicut , India

Received: May 20, 2018

Accepted: May 28, 2018

Online Published: July 25, 2018

\begin{abstract}
This article tests the validity of Capital Asset pricing Model and compares the results of 16 periods including 14 sub periods which comprises 3 years each for the prediction of the expected returns in the Indian capital Market. The tests were conducted on portfolios having different security combinations. By using Black Jenson and Scholes methodology (1972) the study tested the validity of the model for the whole and different sub periods. The study used daily data of the BSE 100 index for the period from January 2001 to December 2010. Empirical results mostly in favor of the standard CAPM model. However, the result does not find conclusive evidence in support of CAPM
\end{abstract}

Keywords: Capital Asset pricing Model, Beta, systematic risk, Security market line.

\section{Introduction}

Globalization and international investments to Indian capital market over the past decade made investment arena tougher and investment decisions complex. Today the market is highly volatile and the investor should be cautious and should identify an appropriate tool to evaluate the risk and return involved in his investment decisions. Normally rational investor will expect high return for bearing risk and the rate of return on the investment should commensurate with the riskiness of the assets. Capital Asset Pricing Model (CAPM) was developed by Sharpe (1964), Lintner (1965), and Mossin (1966) and it has been used widely for determining the risk return relationship in asset management. The core assumption of this model is that contribution of an asset to the variance of the market portfolio is the asset's systematic risk and beta can explain the asset's risk. In other words, rate of return and the risk premium, which will be proportional to assets market risk or beta quantifies the amount of risk that cannot be diversified away.

This study has four testable objectives. It checks the empirical validity of the CAPM in Indian stock market and ascertains the relationship between return of securities and market return. It also compared whether expected rate of return is linearly related with systematic risk and the difference in results while using different security combinations. This study is unique in the sense that it is difficult to find a study, which tested the validity of CAPM in Indian capital market by using different portfolio combination. The analysis was conducted for the whole study period and for different sub periods by using two different set of portfolios and failed to find irrefutable evidence in validating CAPM. The size of the sample and the number of companies used to construct the portfolio is one of the important limitations.

2. Review of Literature

CAPM is the widely applauded model to explain the risk return relation. Large number of studies has been carried out to elucidate the relationship between return and factors which affect return and this has been tested with individual security return and portfolio return. Generally portfolio betas are more precise when compared to the individual security beta and researchers like Black and et.al (1972), Friend and Blume (1973) etc, followed portfolio approach to examine CAPM. In1973 Fama and Mac.Beth tested the linearity between expected return and pre 
ranked historic beta of assets and included squared beta as an additional variable to the basic Capital Asset Pricing Model and found a positive relation between return and risk.

Results of various empirical tests revealed that there is a mixed feeling on the applicability of CAPM in predicting risk return relationship. Studies conducted by (Fama and Mac Beth 1973), (Gibbons and Ferson, 1985) are generally in favor of CAPM. At the same time there is substantial criticism against the CAPM since the mid of 1975 and many empirical studies uncovered various anomalies that were clearly in conflict with the model's predictions. (Ross, 1976) introduced the concept of a multi factor model with the theoretical foundation and presented a number of state variables to explain the expected. (Roll, 1977) argued that one cannot empirically test the CAPM because the construction of the market portfolio as per the theory is impossible. (Basu, 1977) found that when stocks are sorted on earnings-price ratios $(\mathrm{E} / \mathrm{P})$, the expected returns on high $\mathrm{E} / \mathrm{P}$ stocks are higher when compared to the return predicted by the Capital Asset Pricing Model. Similarly (Stattman, 1980) tested the effect of book value on stock return, (Banz, 1981) the size effect. (Bhandari, 1988) the effect of leverage and showed the inefficiency of beta to explain the market returns. In 1992 by using the cross-sectional regression Fama and French examined the validity of CAPM and found that size, book to market, debt equity and earning price should consider in the explanation of expected stock return. Further, Chan et.al (1991) challenged the validity of CAPM. (Bark, 1991) tested the riskreturn relationship for assets by using the CAPM with Fama and Macbeths' two-stage approach and found SharpeLinter-Mossin CAPM frame work is not adequate in the Korean stock market. (Yue, 1997) tested CAPM with multivariate testing based on Gibbon's methodology in Hong Kong market and their results rejected both the Sharpe- Lintner CAPM and Black CAPM at an extremely low level. (Harris et al., 2003), (Fan, 2004), (Malin and et. al, 2004) UK, France and German markets rejected CAPM. (Michailidis et.al, 2006) found that their study do not support the theory's basic hypothesis of CAPM in Greek securities market but explained the excess returns. Pettengill et. al (1995) found valid relationship between beta and returns by using a modified methodology of Fama and MacBeth (1973). (Rahman et al., 2006) in Bangladesh market, (Andor et al., 1999) Hungarian capital market also found positive relationship between beta and ex-post return, concluded that CAPM valid for these markets. Besides this (Majumdar et al., 2007) neither support nor reject (mixed result) the Capital Asset Pricing Model. In Indian context few studies were conducted for analyzing risk- return relationship and studies by (Madhusoodanan, 1997), (Srinivasan, 1988) have generally supported CAPM. Studies by (Rao and Bhole, 1990), (Vaidyanathan, 1995), (Sehgal, 1997), (Sehgal, 2003), (Mohanthy, 2002), (Manjunatha, et.al 2006) questioned the validity of CAPM in Indian context.

While examining the literature it is clear that most of the studies in India used monthly or yearly data and only few studies used daily and weekly data to test the validity of Capital Asset Pricing Model. There is dearth of studies in Indian context and is planned to examine the CAPM by using daily data of 70 companies listed in BSE100-index with two different combinations of portfolios.

3. Objectives of the Research

The main objectives of the study is to revisit the empirical validity of CAPM frame work in Indian stock market by using different set of portfolios. The study will use Black et.al (1972) methodology and Fama and Mac Beth (1973) methodology to test the non linearity.

- To examine the empirical validity of the 'CAPM' in Indian stock market.

- To establish the relationship between return of securities and market return in Indian stock market.

- To check whether expected rate of return is linearly related with systematic risk.

- To compare the result of portfolios with different security combinations.

4. Source and Period of Data

The sample for the study covers nine years daily data of 70 companies of BSE 100 stock Index, a broad-based index, launched in 1989 for the period from 01-01-2001 to 31-12-2009 The data used in this study were sourced from of Prowess- a data base of CMIE and the websites Reserve Bank of India (RBI). The study considers 91 day Treasury bill rate as the proxy for the risk free assets, will better reflects the short term changes in the financial market.

5. Methodology for Testing Capital Asset Pricing Model

Black, Jensen and Scholes (1972) introduced a time series test of the CAPM and the relationship between risk and return has been analyzed systematically. The present study also follows a similar approach will follow portfolio technique and use time series regression of excess portfolio return on excess market return and also cross sectional regression in risk premium form and is expressed by the equation below. In the first step, betas (systematic risk) of individual securities are measured and the beta coefficients of individual securities were calculated for the whole period and for the sub periods. A time series regression between the daily percentage return against the market return is used to get the beta coefficient of each security in the sample and the model is shown below.

$$
\mathrm{Ri}_{\mathrm{t}}-\mathrm{Rf}_{\mathrm{t}}=\alpha \mathrm{i}+\beta \mathrm{i}\left(\mathrm{Rm}_{\mathrm{t}}-\mathrm{Rf}_{\mathrm{t}}\right)+\mathrm{ei}_{\mathrm{t}}
$$


Where: $\mathrm{Ri}_{\mathrm{t}}$ is the rate of return on asset $\mathrm{i}$ (or portfolio) at time $\mathrm{t}, \mathrm{Rf}_{\mathrm{t}}$ is the risk-free rate at time $\mathrm{t}, \mathrm{Rm}_{\mathrm{t}}$ is the rate of return on the market portfolio at time $t$, BSE 30 index is taken as the best proxy for the market portfolio. ei $i_{t}$ is the beta of stock $i, e_{t}$ is the error term of regression equation at time $t$.

In the second stage, for the formation of portfolios individual beta for each stock is arranged on ascending order and stocks were grouped in to portfolios having 10 and 5 stocks each according to their beta value .The first portfolio comprises the first 10/5 securities with lowest beta, the next portfolio with the next 10/5 securities and same method is followed for the formation of other portfolios and there by last portfolio is formed with securities having the highest beta. Then portfolio betas are calculated by using the following model.

Where

$$
r_{p t}=\alpha_{p}+\beta_{p} r_{m t}+e_{p t}
$$

$r_{p t}$ is the average excess portfolio return on time $t, \beta_{p}$ is the estimated portfolio beta, and, e $\mathrm{pt}$ is the error term in the regression equation at time $\mathrm{t}$.

to estimate the ex post security market line for each testing period the portfolio return are regressed against portfolio betas. The model is

Where

$$
r_{p}=\lambda_{0}+\lambda_{1} \beta_{p}+e_{p}
$$

$r_{p}=$ is the average excess return of the portfolio $P, \beta_{p}$ is the beta of the portfolio $P$, and $e_{p}$ is the error term in the regression equation

Further the study will also tested the non- linearity between the total portfolio return and betas by using the following equation.

$$
r_{p}=\lambda_{0}+\lambda_{1} \beta_{p}+\lambda_{2} \beta_{p}^{2}+e_{p}
$$

\section{CAPM in Different Periods.}

To test the validity of CAPM, the study considered whole period data that is (2001-2009) and then the entire test period is divided in to seven different sub periods comprising three years each. The details are shown in Table1 below.

Table 1. Different Portfolio Formation Periods and Testing Periods

\begin{tabular}{lcccccccc}
\hline \multicolumn{1}{c}{ Period } & $\mathbf{1}$ & $\mathbf{2}$ & $\mathbf{3}$ & $\mathbf{4}$ & $\mathbf{5}$ & $\mathbf{6}$ & $\mathbf{7}$ & $\mathbf{8}$ \\
\hline Period Range & $01-09$ & $01-03$ & $02-04$ & $03-05$ & $04-06$ & $05-07$ & $06-08$ & $07-09$ \\
\hline Portfolio Formation & 2001 & 2001 & 2002 & 2003 & 2004 & 2005 & 2006 & 2007 \\
\hline Testing period & 2009 & 2003 & 2004 & 2005 & 2006 & 2007 & 2008 & 2009 \\
\hline
\end{tabular}

\subsection{CAPM in the Whole Study Period (2001-2009) with Portfolios Having Ten Securities}

The study investigated the applicability of CAPM and the data used in this study consists 5259 days observations of 70 stocks listed in the BSE 100 Index. The results for the whole period by using the model (2) are shown in Table 2 below. Portfolio 1(P1) with lowest beta earned the minimum return of $(0.1113)$ and the portfolio 5 with the beta (1.0538) gives the maximum return (0.1997). During the study period the average risk free return is $(0.0163)$ and the average excess return on the market is (0.0669).The CAPM postulates that higher risk beta is associated with higher Table 2.Test Results for Whole Study Period $(2001$ - 2009) $(\mathrm{N}=5259)$ rate of return and the result of the study partially supports this argument since portfolio6 and portfolio7 with highest beta bags less return than portfolio 5.

\begin{tabular}{cccccccc}
\hline $\begin{array}{c}\text { Port } \\
\text { folio }\end{array}$ & $\begin{array}{l}\text { Portfolio } \\
\text { Return(rp) }\end{array}$ & Intercept & Beta & $\begin{array}{l}\text { Standard } \\
\text { Error }\end{array}$ & R2 & $\begin{array}{c}\text { F value } \\
\text { P Value of } \\
\text { Beta at 99\% }\end{array}$ \\
\hline P1 & 0.11130 & $0.07971 * * *$ & 0.47233 & 0.76289 & 0.54509 & 2688.93 & 0.0000 \\
\hline P2 & 0.11554 & $0.06680 * * *$ & 0.72892 & 0.97319 & 0.63685 & 3935.33 & 0.0000 \\
\hline P3 & 0.12702 & $0.06868 * *$ & 0.87242 & 0.79571 & 0.78981 & 8432.46 & 0.0000 \\
\hline P4 & 0.13047 & $0.06646 * *$ & 0.95720 & 0.90286 & 0.77844 & 7884.51 & 0.0000 \\
\hline P5 & 0.19971 & $0.12924 * * *$ & 1.05378 & 0.91577 & 0.80541 & 9288.38 & 0.0000 \\
\hline P6 & 0.16271 & $0.08401 * * *$ & 1.17683 & 1.09133 & 0.78425 & 8156.95 & 0.0000 \\
\hline P7 & 0.18238 & $0.09388^{* * *}$ & 1.32345 & 1.20891 & 0.78931 & 8406.92 & 0.0000 \\
\hline Avg Rf & 0.01626 & Average & $\mathrm{rm}=(\mathrm{Rm}-\mathrm{Rf})$ & 0.06687 & $* * *$ significant at $99 \%$ level. \\
\hline
\end{tabular}


R-square explains the relative amount of the variance in return of a particular portfolio with the return on index. In the case of portfolio 1 , the $\mathrm{R}^{2}$ value is $(0.54509)$, which indicates less than adequate correlation with the market index. Were as in portfolio $5, \mathrm{R}^{2}$ value is $(0.80541)$, which indicates that above 80 per cent of the variation in the scrip has been explained by the relationship with the index. The positive constants suggest that the portfolios have earned higher returns than the CAPM has predicted. Thus from the analysis it is clear that in most of the cases $\beta$ is a predictor of return in Indian capital market during the study period but there no conclusive evidence in favor of CAPM.

6.1.1 Test of Non-Linearity (2001-2009)

Test for the non-linearity helps one to check whether there exists non-linearity between portfolio return with beta. As per theory, if CAPM holds true $\lambda_{0}$ and $\lambda_{2}$ will be equal to zero and the $\lambda_{1}$ will be equal to the average risk premium. In this work the non-linearity has been tested by using the regression model (4). The results of the estimated values are summarized in the Table 3; it shows that the value of the constant $\lambda 0$ is not significantly different from zero. Statistically the $\mathrm{t}$ - value is $(0.8377)$, which is less than $(2.7765)$ at $5 \%$ significant level and thereby it is consistent with the argument of CAPM.

Table 3. Test of Non-Linearity for the Whole Period (2001 - 2009)

\begin{tabular}{ccccc}
\hline & Coefficients & Std error & t- value & p-value \\
\hline$\lambda_{\mathbf{0}}$ & 0.08368 & 0.09989 & 0.8377 & 0.4493 \\
\hline$\lambda_{1}$ & 0.02685 & 0.23162 & 0.1159 & 0.9133 \\
\hline$\lambda_{2}$ & 0.03990 & 0.12751 & 0.3130 & 0.7699 \\
\hline
\end{tabular}

Critical value for 4-Degrees of freedom (2.7765)

In the case of $\lambda_{1}$, the t- value is (0.1159) is smaller than (2.7765), and it is not significantly different from zero. As per the CAPM, the $\lambda_{1}$ should be equal to the average risk premium; hence the result is inconsistent with the CAPM hypothesis. In the case of $\lambda_{2}$, the value (0.3130) and the t-value is less than $(2.7765)$ at $5 \%$ significance level and thereby it is consistent with the CAPM hypothesis. Thus, it is clear tha betas are linearly related with expected return. Hence CAPM cannot be clearly rejected during the study period.

6.2. CAPM in Different Sub Periods

6.2.1 Consolidated Test Results for Different Sub - Periods (Ten Securities)

CAPM is tested for different study period by using portfolios having 10 securities. The results for different study periods are summarized below in Tables 4 to 7. The findings are mostly supportive in different test periods to the hypothesis of Capital Asset Pricing Model, which says that higher beta provides higher return to the investor. Study reveals that while using percentage return and portfolios with equal weight, in most of the case beta explain the variation in portfolio returns, in few periods lower beta earned more return than higher beta portfolios, which is clear from table. 4 .

Table 4. Consolidated Results for Different Sub Periods by Using 10 Securities

\begin{tabular}{|c|c|c|c|c|c|c|c|c|c|c|c|c|}
\hline \multirow{2}{*}{$\begin{array}{l}\text { Port } \\
\text { folio }\end{array}$} & \multicolumn{6}{|c|}{ Sub period $1(20001-2003)$} & \multicolumn{6}{|c|}{ Sub period $2(2002-2004)$} \\
\hline & $\begin{array}{c}\text { Portfolio } \\
\text { return }\end{array}$ & Constant & Beta & $\mathbf{R 2}$ & $\begin{array}{c}\text { F } \\
\text { Value }\end{array}$ & $\begin{array}{c}\mathbf{P} \\
\text { value } \\
\text { Beta }\end{array}$ & $\begin{array}{c}\text { Portfolio } \\
\text { return }\end{array}$ & Constant & Beta & F Value & $\mathbf{R 2}$ & $\begin{array}{c}\mathbf{P} \\
\text { value } \\
\text { Beta }\end{array}$ \\
\hline P1 & 0.1358 & $0.1189 * * *$ & 0.34760 & 0.2715 & 279.90 & 0.0000 & 0.18812 & $0.1456 * * *$ & 0.40544 & 390.38 & 0.3402 & 0.0000 \\
\hline $\mathrm{P} 2$ & 0.1988 & $0.1709 * * *$ & 0.57192 & 0.3664 & 434.37 & 0.0000 & 0.13299 & $0.0651 * * *$ & 0.64687 & 1315.22 & 0.6347 & 0.0000 \\
\hline P3 & 0.1438 & $0.1084 * * *$ & 0.72707 & 0.5547 & 935.38 & 0.0000 & 0.27030 & $0.1820 * * *$ & 0.84115 & 1378.53 & 0.6455 & 0.0000 \\
\hline $\mathrm{P} 4$ & 0.1821 & $0.1415^{* * * *}$ & 0.83370 & 0.5541 & 933.16 & 0.0000 & 0.20948 & $0.1071 * * *$ & 0.97486 & 1317.89 & 0.6352 & 0.0000 \\
\hline P5 & 0.2164 & $0.1702 * * *$ & 0.94681 & 0.5903 & 1081.92 & 0.0000 & 0.23339 & $0.1177 * * *$ & 1.10212 & 2776.67 & 0.7858 & 0.0000 \\
\hline P6 & 0.2196 & $0.1668 * * *$ & 1.08355 & 0.5961 & 1108.22 & 0.0000 & 0.27087 & 0.1415 *** & 1.23187 & 2449.39 & 0.7639 & 0.0000 \\
\hline P7 & 0.1284 & 0.0514 & 1.57857 & 0.7688 & 2496.59 & 0.0000 & 0.27020 & $0.1172 * * *$ & 1.45715 & 2179.65 & 0.7422 & 0.0000 \\
\hline $\begin{array}{c}\text { Avg } \\
\text { Rf }\end{array}$ & 0.01681 & Average & $\mathrm{rm}=(\mathrm{Rr}$ & -Rf) & 0.04 & & Avg Rf & 0.0142 & Average $r$ & (Rm-Rf) & 0.10 & 498 \\
\hline
\end{tabular}

$* * *$ significant at $99 \%$ 
Table 5. Consolidated Results for Different Sub Periods by Using 10 Securities

\begin{tabular}{|c|c|c|c|c|c|c|c|c|c|c|c|c|}
\hline \multirow{2}{*}{$\begin{array}{l}\text { Port } \\
\text { folio }\end{array}$} & \multicolumn{6}{|c|}{ Sub period 3(2003-2005) } & \multicolumn{6}{|c|}{ Sub period $4(2004-2006)$} \\
\hline & $\begin{array}{c}\text { Portfolio } \\
\text { return }\end{array}$ & Constant & Beta & $\mathbf{R 2}$ & $\begin{array}{c}F \\
\text { Value }\end{array}$ & $\begin{array}{c}\mathbf{P} \\
\text { value } \\
\text { Beta }\end{array}$ & $\begin{array}{l}\text { Portfolio } \\
\text { return }\end{array}$ & Constant & Beta & $\mathbf{R 2}$ & $\begin{array}{c}F \\
\text { Value }\end{array}$ & $\begin{array}{c}\mathbf{P} \\
\text { value } \\
\text { Beta }\end{array}$ \\
\hline P1 & 0.19576 & $0.1312^{* * *}$ & 0.46072 & 0.39166 & 487.370 & 0.0000 & 0.19367 & $0.13865 * * *$ & 0.56299 & 0.53150 & 854.283 & 0.0000 \\
\hline $\mathrm{P} 2$ & 0.23213 & $0.1359 * * *$ & 0.69667 & 0.64385 & 1368.55 & 0.0000 & 0.13098 & $0.04788^{* * *}$ & 0.81057 & 0.77784 & 2636.53 & 0.0000 \\
\hline $\mathrm{P} 3$ & 0.19582 & $0.0762 * * *$ & 0.84995 & 0.73712 & 2122.70 & 0.0000 & 0.18110 & $0.09071 * * *$ & 0.89768 & 0.78512 & 2751.36 & 0.0000 \\
\hline P4 & 0.24712 & $0.1152 * * *$ & 0.94406 & 0.70782 & 1833.88 & 0.0000 & 0.16977 & $0.07077 * * *$ & 0.97381 & 0.81428 & 3301.59 & 0.0000 \\
\hline P5 & 0.24341 & $0.0943 * * *$ & 1.06785 & 0.84625 & 4166.87 & 0.0000 & 0.13713 & 0.02389 & 1.1060 & 0.81169 & 3245.86 & 0.0000 \\
\hline P6 & 0.23194 & $0.0589 * *$ & 1.24122 & 0.74919 & 2261.24 & 0.0000 & 0.17221 & $0.04885^{*}$ & 1.20218 & 0.84072 & 3974.74 & 0.0000 \\
\hline P7 & 0.27509 & $0.0690 * *$ & 1.47422 & 0.79990 & 3026.13 & 0.0000 & 0.17639 & 0.02408 & 1.48129 & 0.84064 & 3972.28 & 0.0000 \\
\hline $\begin{array}{l}\text { Avg } \\
\text { Rf }\end{array}$ & 0.01366 & Average & $\mathrm{rm}=(\mathrm{R}$ & $n-R f)$ & 0.13 & & Avg Rf & 0.0142 & Average $\mathrm{r}$ & $=(\mathrm{Rm}-\mathrm{Rf})$ & 0.10 & \\
\hline
\end{tabular}

*** Significant at $99 \%, * *$ Significant at $95 \%, *$ Significant at $90 \%$

Table 6. Consolidated Results for Different Sub Periods by Using 10 Securities

\begin{tabular}{|c|c|c|c|c|c|c|c|c|c|c|c|c|}
\hline \multirow{2}{*}{$\begin{array}{l}\text { Port } \\
\text { folio }\end{array}$} & \multicolumn{6}{|c|}{ Sub period $5(2005-2007)$} & \multicolumn{6}{|c|}{ Sub period $6(2006-2008)$} \\
\hline & $\begin{array}{l}\text { Portfolio } \\
\text { return }\end{array}$ & Constant & Beta & $\mathbf{R 2}$ & $\begin{array}{c}\mathbf{F} \\
\text { Value }\end{array}$ & $\begin{array}{c}\mathbf{P} \\
\text { value } \\
\text { Beta } \\
\end{array}$ & $\begin{array}{l}\text { Portfolio } \\
\text { return }\end{array}$ & Constant & Beta & $\mathbf{R 2}$ & $\begin{array}{c}\text { F } \\
\text { Value }\end{array}$ & $\begin{array}{c}P \\
\text { value } \\
\text { Beta }\end{array}$ \\
\hline $\mathrm{P} 1$ & 0.27919 & 0.0613 & 1.4924 & 0.8002 & 2997.27 & 0.0000 & 0.05494 & $0.05317 *$ & 0.4755 & 0.59363 & 1085.4 & 0.0000 \\
\hline $\mathrm{P} 2$ & 0.28746 & 0.0672 & 1.5099 & 0.7860 & 2748.69 & 0.0000 & 0.00965 & 0.00700 & 0.7117 & 0.77526 & 2563.1 & 0.0000 \\
\hline $\mathrm{P} 3$ & 0.30661 & $0.0858 * *$ & 1.5166 & 0.7784 & 2628.29 & 0.0000 & 0.03012 & 0.02690 & 0.8655 & 0.81634 & 3302.5 & 0.0000 \\
\hline $\mathrm{P} 4$ & 0.31259 & $0.0911 * *$ & 1.5203 & 0.7617 & 2391.5 & 0.0000 & -0.01330 & 0.01678 & 0.9389 & 0.86496 & 4759.4 & 0.0000 \\
\hline $\mathrm{P} 5$ & 0.30497 & $0.0842 *$ & 1.5222 & 0.7771 & 2608.02 & 0.0000 & 0.05991 & $0.05603 * *$ & 1.0439 & 0.90513 & 7088.8 & 0.0000 \\
\hline P6 & 0.30914 & $0.0865 * *$ & 1.52323 & 0.7822 & 2686.45 & 0.0000 & 0.06231 & 0.05787 & 1.1944 & 0.86683 & 4836.6 & 0.0000 \\
\hline $\mathrm{P} 7$ & 0.31722 & $0.0972 * *$ & 1.52382 & 0.7717 & 2529.03 & 0.0000 & 0.12303 & $0.11767 * * *$ & 1.4412 & 0.87329 & 5120.82 & 0.0000 \\
\hline $\begin{array}{l}\text { Avg } \\
\text { Rf }\end{array}$ & 0.01724 & Average & $\mathrm{rm}=(\mathrm{Rn}$ & -Rf) & 0.14 & & Avg Rf & 0.01939 & Average & $=(\mathrm{Rm}-\mathrm{Rf})$ & 0.00 & \\
\hline
\end{tabular}

*** Significant at99\%, ** Significant at95\%, Note: The Values of Constant, F, Pand $\mathrm{R}^{2}$ are adjusted to 4 digits.

Table 7. Consolidated Results for Different Sub Periods by Using 10 Securities

\begin{tabular}{|c|c|c|c|c|c|c|}
\hline \multirow{2}{*}{$\begin{array}{l}\text { Port } \\
\text { folio }\end{array}$} & \multicolumn{6}{|c|}{ Sub period $7(2007-2009)$} \\
\hline & $\begin{array}{c}\text { Portfolio } \\
\text { return }\end{array}$ & Constant & Beta & $\mathbf{R 2}$ & $\begin{array}{c}\mathbf{F} \\
\text { Value }\end{array}$ & $\begin{array}{c}\text { P value } \\
\text { Beta }\end{array}$ \\
\hline $\mathrm{P} 1$ & 0.08502 & $0.06672 * *$ & 0.393851 & 0.53903 & 860.651 & 0.0000 \\
\hline $\mathrm{P} 2$ & 0.04054 & 0.00929 & 0.67844 & 0.73441 & 2035.23 & 0.0000 \\
\hline $\mathrm{P} 3$ & 0.08185 & 0.04320 & 0.82771 & 0.79910 & 2927.60 & 0.0000 \\
\hline $\mathrm{P} 4$ & 0.08081 & 0.03690 & 0.93784 & 0.83494 & 3723.10 & 0.0000 \\
\hline P5 & 0.11927 & $0.06948 * *$ & 1.04698 & 0.84949 & 5719.99 & 0.0000 \\
\hline P6 & 0.16448 & $0.10719^{* * *}$ & 1.23770 & 0.87192 & 5010.55 & 0.0000 \\
\hline $\mathrm{P} 7$ & 0.12786 & 0.05648 & 1.47794 & 0.88429 & 5624.87 & 0.0000 \\
\hline$\overline{\text { Avg Rf }}$ & 0.04611 & Average & $\mathrm{rm}=(\mathrm{Rr}$ & -Rf) & & \\
\hline
\end{tabular}

6.2.2 Test of Non-Linearity

The test for the non- linearity (Table 8-10) reveals that, for whole and adjusted period result support CAPM hypothesis. In addition high value of estimated correlation coefficient between the intercept and the slope indicates that the model explains excess returns 
Table 8.Consolidated Results for Different Study Periods by Using 10 Securities

\begin{tabular}{|c|c|c|c|c|c|c|c|c|c|}
\hline \multirow[t]{2}{*}{ Coefficient } & \multicolumn{3}{|c|}{ Whole Period (2001-2009) } & \multicolumn{3}{|c|}{ Sub Period 1(2001-2003) } & \multicolumn{3}{|c|}{ Sub Period 2(2002-2004) } \\
\hline & Constant & t -value & P value & Constant & t- value & $P$ value & $\begin{array}{c}\text { Constan } \\
\mathbf{t}\end{array}$ & t- value & $P$ value \\
\hline$\lambda 0$ & 0.0837 & 0.8377 & 0.4493 & 0.03810 & 0.5678 & 0.6005 & 0.12757 & 1.0150 & 0.3674 \\
\hline$\lambda 1$ & 0.0269 & 0.1159 & 0.9133 & 0.33520 & 2.252 & 0.0874 & 0.0991 & 0.3444 & 0.7479 \\
\hline$\lambda 2$ & 0.0399 & 0.3130 & 0.7699 & -0.1736 & -2.326 & 0.0806 & 0.0030 & 0.0201 & 0.9849 \\
\hline
\end{tabular}

Table 9. Consolidated Results for Different Study Periods by Using 10 Securities

\begin{tabular}{cccccccccc}
\hline & \multicolumn{3}{c}{ Sub Period 3(2003-2005) } & \multicolumn{2}{c}{ Sub Period 4(2004-2006) } & \multicolumn{2}{c}{ Sub Period 5 (2005-2007) } \\
\cline { 2 - 9 } Coefficient & Constant & t- value & P value & Constant & t- value & P value & Constant & t- value & P value \\
\hline$\lambda 0$ & 0.1839 & 2.6050 & 0.0597 & 0.2984 & 2.766 & 0.0505 & 60.2641 & 1.055 & 0.3509 \\
\hline$\lambda 1$ & 0.0298 & 0.1946 & 0.8552 & -0.2699 & -1.244 & 0.2815 & -80.6609 & -1.065 & 0.3469 \\
\hline$\lambda 2$ & 0.0186 & 0.2389 & 0.8229 & 0.12792 & 1.224 & 0.2881 & 27.1154 & 1.080 & 0.3410 \\
\hline
\end{tabular}

Table 10. Consolidated Results for Different Study Periods by Using 10 Securities

\begin{tabular}{ccccccc}
\hline \multirow{2}{*}{ Coefficient } & \multicolumn{3}{c}{ Sub Period 6 (2006-2008) } & \multicolumn{2}{c}{ Sub Period 7(2007-2009) } \\
\cline { 2 - 6 } & Constant & t- value & P value & Constant & t- value & P value \\
\hline$\lambda 0$ & 0.2037 & 2.393 & 0.0750 & 0.0647 & 0.7213 \\
\hline$\lambda 1$ & -0.4595 & -2.485 & 0.0678 & -0.0185 & -0.0924 & 0.5106 \\
\hline$\lambda 2$ & 0.2826 & $2.975 * *$ & 0.0410 & 0.0529 & 0.5030 \\
\hline
\end{tabular}

6.3 CAPM Frame Work in Indian Capital Market (Portfolios with Five Securities)

In this section an attempt is made to test the empirical validity of the CAPM by using portfolios having five securities. The theory says that through diversification one can strategically reduce the risk by allocating available funds in many securities by forming balanced portfolios. Further, this test will also help us to compare the results with our studies with same set of data and also to check whether number of securities in a portfolio has any influence on measuring the efficiency and validity of CAPM.

While analyzing table 11 , it is clear that out of the14 portfolios, with the increase in beta we cannot see any increasing trend in the average portfolio excess return; rather it comes up and down. Results also supplement that, all portfolios including portfolio with lowest beta earned more than the average excess market return and the risk free return. Further the positive constants suggest that, the portfolios earned higher returns than the CAPM has predicted. Further from the Table11, it can be noted that the all constants has positive values. Thus the result indicates that, the alpha coefficients are significantly different from zero and hence we reject the null hypothesis. Further all estimated betas are found to be statistically significant at $99 \%$ level; thereby we reject the null hypothesis that the portfolio beta is not a significant determinant of portfolio return. Thus $\beta$ is a predictor of return during the whole study period (2001-2009).

Table 11.Results of the Whole Study Period (2001 - 2009)

\begin{tabular}{cccccccc}
\hline Port folio & $\begin{array}{c}\text { Portfolio } \\
\text { Return(rp) }\end{array}$ & Constant & Beta & $\begin{array}{c}\text { Standard } \\
\text { Error }\end{array}$ & R2 & F value & $\begin{array}{c}\text { P Value } \\
\mathbf{9 9 \%}\end{array}$ \\
\hline P1 & 0.08861 & 0.06414 & 0.36583 & 0.92121 & 0.33020 & 1106.26 & 0.0000 \\
\hline P2 & 0.13393 & 0.09521 & 0.57899 & 1.09383 & 0.46691 & 1965.43 & 0.0000 \\
\hline P3 & 0.12553 & 0.07899 & 0.69593 & 1.38381 & 0.44153 & 1774.18 & 0.0000 \\
\hline P4 & 0.10556 & 0.05461 & 0.76191 & 1.05857 & 0.61823 & 3633.93 & 0.0000 \\
\hline P5 & 0.13207 & 0.07543 & 0.84704 & 1.06828 & 0.66276 & 4410.18 & 0.0000 \\
\hline
\end{tabular}




\begin{tabular}{cccccccc}
\hline P6 & 0.12198 & 0.06193 & 0.89781 & 1.09352 & 0.67816 & 4728.54 & 0.0000 \\
\hline P7 & 0.13557 & 0.07309 & 0.93429 & 1.14146 & 0.67682 & 4699.57 & 0.0000 \\
\hline P8 & 0.12536 & 0.05982 & 0.98011 & 1.22015 & 0.66855 & 4526.25 & 0.0000 \\
\hline P9 & 0.18670 & 0.11754 & 1.03411 & 1.11044 & 0.73053 & 6083.59 & 0.0000 \\
\hline P10 & 0.21272 & 0.14094 & 1.07345 & 1.30458 & 0.67912 & 4749.29 & 0.0000 \\
\hline P11 & 0.18653 & 0.10890 & 1.16086 & 1.68331 & 0.59786 & 3336.14 & 0.0000 \\
\hline P12 & 0.13889 & 0.05912 & 1.19280 & 1.29372 & 0.72657 & 5962.97 & 0.0000 \\
\hline P13 & 0.18345 & 0.10019 & 1.24502 & 1.51927 & 0.67734 & 4710.72 & 0.0000 \\
\hline P14 & 0.18131 & 0.08756 & 1.40188 & 1.44521 & 0.74628 & 6600.44 & 0.0000 \\
\hline Avg Rf & 0.01626 & \multicolumn{2}{c}{ Average } \\
\end{tabular}

6.4 Consolidated result for the sub periods (Five securities)

In the second Phase test is repeated with five securities by using same methodology and procedure by constructing 14 portfolios for different sub periods and results for different study periods are summarized below in Table 12 to 15.

6.5 Through Portfolios having five securities each.

Table 12. Consolidated Results for Different Sub Periods by Using 5 Securities

\begin{tabular}{|c|c|c|c|c|c|c|c|c|c|c|c|c|}
\hline \multirow{2}{*}{$\begin{array}{l}\text { Port } \\
\text { folio }\end{array}$} & \multicolumn{6}{|c|}{ Sub period 1 (20001-2003) } & \multicolumn{6}{|c|}{ Sub period $2(2002-2004)$} \\
\hline & $\begin{array}{c}\text { Portfolio } \\
\text { return }\end{array}$ & Constant & Beta & $\mathbf{R 2}$ & $\begin{array}{c}\text { F } \\
\text { Value }\end{array}$ & $\begin{array}{c}\mathbf{P} \\
\text { value } \\
\text { Beta }\end{array}$ & $\begin{array}{c}\text { Portfolio } \\
\text { return }\end{array}$ & Constant & Beta & F Value & $\mathbf{R 2}$ & $\begin{array}{c}\mathbf{P} \\
\text { value } \\
\text { Beta }\end{array}$ \\
\hline $\mathrm{P} 1$ & 0.19742 & $0.18649 * * *$ & 0.224016 & 0.05953 & 47.543 & 0.0000 & 0.17171 & $0.13756 * * *$ & 0.32533 & 0.15175 & 135.43 & 0.000 \\
\hline $\mathrm{P} 2$ & 0.07307 & $0.05011 * * *$ & 0.47042 & 0.32234 & 357.22 & 0.0000 & 0.20452 & $0.15354 * * *$ & 0.48554 & 0.28184 & 297.09 & 0.000 \\
\hline P3 & 0.11733 & $0.09139 * * *$ & 0.53131 & 0.35932 & 421.19 & 0.0000 & 0.09170 & 0.02911 & 0.59613 & 0.46562 & 659.59 & 0.000 \\
\hline $\mathrm{P} 4$ & 0.28033 & $0.25043 * * *$ & 0.61253 & 0.19548 & 182.48 & 0.0000 & 0.17428 & $0.10105 * * *$ & 0.69761 & 0.52564 & 838.85 & 0.000 \\
\hline P5 & 0.14339 & $0.11568 * * *$ & 0.56765 & 0.67610 & 1567.61 & 0.0000 & 0.23518 & $0.15026 * * *$ & 0.80884 & 0.54483 & 906.11 & 0.000 \\
\hline P6 & 0.17951 & $0.14242 * * *$ & 0.75989 & 0.43036 & 567.39 & 0.0000 & 0.30542 & $0.21372 * * *$ & 0.87345 & 0.48309 & 707.48 & 0.000 \\
\hline P7 & 0.17044 & $0.13072 * * *$ & 0.81355 & 0.43529 & 578.89 & 0.0000 & 0.29151 & $0.19444 * * *$ & 0.92460 & 0.42010 & 548.40 & 0.000 \\
\hline $\mathrm{P} 8$ & 0.19392 & $0.15224 * * *$ & 0.85385 & 0.48513 & 707.62 & 0.0000 & 0.12744 & 0.01982 & 1.02513 & 0.54577 & 909.55 & 0.000 \\
\hline P9 & 0.20621 & $0.16085^{* * *}$ & 0.92927 & 0.49174 & 726.60 & 0.0000 & 0.21617 & $0.10394 * * *$ & 1.06901 & 0.67917 & 1602.54 & 0.000 \\
\hline $\mathrm{P} 10$ & 0.22664 & $0.17956 * * *$ & 0.96435 & 0.45395 & 624.35 & 0.0000 & 0.25062 & $0.13144 * * *$ & 1.13524 & 0.64087 & 1350.90 & 0.000 \\
\hline P11 & 0.23548 & $0.18411 * * *$ & 1.05245 & 0.44146 & 593.58 & 0.0000 & 0.29870 & $0.17431 * * *$ & 1.18485 & 0.59285 & 1102.28 & 0.000 \\
\hline P12 & 0.20380 & $0.14939 * * *$ & 1.11465 & 0.54388 & 895.50 & 0.0000 & 0.24304 & $0.10877 * *$ & 1.27889 & 0.69318 & 1710.29 & 0.000 \\
\hline P13 & 0.20038 & 0.13433 & 1.35309 & 0.57866 & 1031.42 & 0.0000 & 0.24396 & $0.10043 * * *$ & 1.36722 & 0.66184 & 1481.60 & 0.000 \\
\hline P14 & 0.05651 & -0.0315 & 1.80405 & 0.60889 & 1169.21 & 0.0000 & 0.29643 & $0.13401 * *$ & 1.54707 & 0.63798 & 1334.06 & 0.000 \\
\hline $\begin{array}{c}\text { Avg } \\
\text { Rf }\end{array}$ & 0.01681 & Average & $\mathrm{rm}=(\mathrm{Rn}$ & -Rf) & 0.04 & & Avg Rf & 0.0142 & Average $\mathrm{r}$ & $=(\mathrm{Rm}-\mathrm{Rf})$ & 0.10 & \\
\hline
\end{tabular}

Table 13. Consolidated Results for Different Sub Periods by Using 5 Securities

\begin{tabular}{|c|c|c|c|c|c|c|c|c|c|c|c|c|}
\hline \multirow{2}{*}{$\begin{array}{l}\text { Port } \\
\text { folio }\end{array}$} & \multicolumn{6}{|c|}{ Sub period $3(20003-2005)$} & \multicolumn{6}{|c|}{ Sub period 4 (2004-2006) } \\
\hline & $\begin{array}{c}\text { Portfolio } \\
\text { return }\end{array}$ & Constant & Beta & $\mathbf{R 2}$ & $\begin{array}{c}\text { F } \\
\text { Value }\end{array}$ & $\begin{array}{c}\mathbf{P} \\
\text { value } \\
\text { Beta }\end{array}$ & $\begin{array}{c}\text { Portfolio } \\
\text { return }\end{array}$ & Constant & Beta & F Value & $\mathbf{R 2}$ & $\begin{array}{c}\mathbf{P} \\
\text { value } \\
\text { Beta }\end{array}$ \\
\hline $\mathrm{P} 1$ & 0.24929 & $0.20095 * * *$ & 0.34627 & 0.05431 & 43.47 & 0.0000 & 0.28197 & $0.23574 * * *$ & 0.44003 & 0.24059 & 238.56 & 0.0000 \\
\hline $\mathrm{P} 2$ & 0.20172 & $0.12413 * * *$ & 0.55581 & 0.33865 & 387.63 & 0.0000 & 0.10538 & 0.03384 & 0.68098 & 0.54276 & 893.85 & 0.0000 \\
\hline P3 & 0.20792 & $0.11751 * * *$ & 0.64766 & 0.52264 & 828.82 & 0.0000 & 0.14888 & 0.06619 & 0.78709 & 0.59590 & 1110.41 & 0.0000 \\
\hline $\mathrm{P} 4$ & 0.25831 & $0.15440 * * *$ & 0.74439 & 0.45755 & 638.53 & 0.0000 & 0.11308 & 0.02567 & 0.83205 & 0.68855 & 1664.72 & 0.0000 \\
\hline P5 & 0.23397 & $0.12034 * * *$ & 0.81396 & 0.57012 & 1003.95 & 0.0000 & 0.17716 & $0.08494 * *$ & 0.87792 & 0.65463 & 1427.33 & 0.0000 \\
\hline P6 & 0.15640 & 0.03245 & 0.88791 & 0.60786 & 1173.46 & 0.0000 & 0.18503 & $0.08919 * *$ & 0.91237 & 0.67145 & 1538.93 & 0.0000 \\
\hline
\end{tabular}




\begin{tabular}{|c|c|c|c|c|c|c|c|c|c|c|c|c|}
\hline P7 & 0.18686 & 0.05801 & 0.92303 & 0.61339 & 1201.05 & 0.0000 & 0.20167 & $0.10168 * * *$ & 0.95182 & 0.63368 & 1302.60 & 0.0000 \\
\hline P8 & 0.30750 & $0.17265 * * *$ & 0.96590 & 0.54568 & 909.245 & 0.0000 & 0.13786 & 0.03367 & 0.99184 & 0.74699 & 2223.26 & 0.0000 \\
\hline P9 & 0.21573 & $0.07267 * *$ & 1.02480 & 0.67206 & 1551.36 & 0.0000 & 0.12929 & 0.01800 & 1.05944 & 0.81215 & 3255.66 & 0.0000 \\
\hline P10 & 0.27128 & $0.11611 * * *$ & 1.11157 & 0.70056 & 1771.07 & 0.0000 & 0.14496 & 0.02424 & 1.14913 & 0.63506 & 1310.39 & 0.0000 \\
\hline $\mathrm{P} 11$ & 0.23793 & $0.06852 *$ & 1.21355 & 0.72147 & 1960.87 & 0.0000 & 0.09773 & -0.0250 & 1.16838 & 0.79510 & 2922.04 & 0.0000 \\
\hline $\mathrm{P} 12$ & 0.22874 & 0.05149 & 1.26967 & 0.60091 & 1139.83 & 0.0000 & 0.24669 & $0.11720 * * *$ & 1.23260 & 0.70469 & 1796.91 & 0.0000 \\
\hline P13 & 0.30853 & $0.11609 * * *$ & 1.37849 & 0.64444 & 1372.07 & 0.0000 & 0.12800 & -0.01909 & 1.40033 & 0.77133 & 2539.94 & 0.0000 \\
\hline P14 & 0.24079 & $0.02146 * * *$ & 1.57112 & 0.72060 & 1952.39 & 0.0000 & 0.22479 & 0.06110 & 1.55817 & 0.76394 & 2436.99 & 0.0000 \\
\hline $\begin{array}{c}\text { Avg } \\
\text { Rf }\end{array}$ & 0.01366 & Average & $\mathrm{rm}$ & Rf) & 0 . & & $\mathrm{Rf}$ & 0.01496 & Average & -Rf) & & \\
\hline
\end{tabular}

$* * *$ Significant at $99 \%, * *$ Significant at $95 \% *$ significant at 90

Table 14. Consolidated Results for Different Sub Periods by Using 5 Securities

\begin{tabular}{|c|c|c|c|c|c|c|c|c|c|c|c|c|}
\hline \multirow{2}{*}{$\begin{array}{l}\text { Port } \\
\text { folio }\end{array}$} & \multicolumn{6}{|c|}{ Sub Period 5 (2005-2007) } & \multicolumn{6}{|c|}{ Sub period $6(2006-2008)$} \\
\hline & $\begin{array}{c}\text { Portfolio } \\
\text { return }\end{array}$ & Constant & Beta & $\mathbf{R 2}$ & $\begin{array}{c}\text { F } \\
\text { Value }\end{array}$ & $\begin{array}{c}\mathbf{P} \\
\text { value } \\
\text { Beta }\end{array}$ & $\begin{array}{c}\text { Portfolio } \\
\text { return }\end{array}$ & Constant & Beta & F Value & $\mathbf{R 2}$ & $\begin{array}{c}\mathbf{P} \\
\text { value } \\
\text { Beta }\end{array}$ \\
\hline $\mathrm{P} 1$ & 0.18841 & $0.12317 * * *$ & 0.45032 & 0.27014 & 276.86 & 0.0000 & 0.04525 & 0.04382 & 0.382707 & 0.37697 & 449.574 & 0.0000 \\
\hline $\mathrm{P} 2$ & 0.05039 & -0.0449 & 0.65794 & 0.45728 & 630.24 & 0.0000 & 0.06464 & 0.06252 & 0.568486 & 0.52345 & 816.136 & 0.0000 \\
\hline P3 & 0.09877 & -0.0093 & 0.74606 & 0.55341 & 926.918 & 0.0000 & -0.00058 & -0.0030 & 0.674543 & 0.62702 & 1249.06 & 0.0000 \\
\hline $\mathrm{P} 4$ & 0.16718 & 0.05084 & 0.80304 & 0.61659 & 1202.75 & 0.0000 & 0.01988 & 0.01709 & 0.749013 & 0.68243 & 1596.64 & 0.0000 \\
\hline P5 & 0.27100 & 0.14695 *** & 0.85632 & 0.63024 & 1274.93 & 0.0000 & -0.0127 & -0.0158 & 0.841287 & 0.68243 & 1596.65 & 0.0000 \\
\hline $\mathrm{P} 6$ & 0.30328 & 0.17368 *** & 0.89459 & 0.51774 & 803.03 & 0.0000 & 0.07296 & $0.06965 *$ & 0.889805 & 0.72932 & 2001.94 & 0.0000 \\
\hline P7 & 0.17761 & 0.04330 & 0.92708 & 0.71130 & 1842.96 & 0.0000 & -0.05857 & -0.0619 & 0.918755 & 0.74232 & 2140.44 & 0.0000 \\
\hline $\mathrm{P} 8$ & 0.19412 & 0.05283 & 0.97526 & 0.68251 & 1608.00 & 0.0000 & 0.03197 & 0.02840 & 0.959227 & 0.78576 & 2725.07 & 0.0000 \\
\hline P9 & 0.16470 & 0.01685 & 1.02056 & 0.85017 & 4244.59 & 0.0000 & 0.02223 & 0.01848 & 1.00811 & 0.80510 & 3069.29 & 0.0000 \\
\hline P10 & 0.19538 & 0.03938 & 1.07679 & 0.73240 & 2047.21 & 0.0000 & 0.09760 & $0.09358 * *$ & 1.07988 & 0.83894 & 3870.42 & 0.0000 \\
\hline $\mathrm{P} 11$ & 0.21096 & 0.04895 & 1.11830 & 0.76155 & 2389.04 & 0.0000 & 0.07970 & $0.07545^{*}$ & 1.14211 & 0.80342 & 3036.71 & 0.0000 \\
\hline P12 & 0.22037 & 0.04218 & 1.23002 & 0.69938 & 1740.26 & 0.0000 & 0.04492 & 0.04028 & 1.24674 & 0.78747 & 2753.06 & 0.0000 \\
\hline P13 & 0.23825 & 0.02799 & 1.45135 & 0.69469 & 1701.98 & 0.0000 & 0.15627 & $0.15127 * * *$ & 1.34516 & 0.79343 & 2853.99 & 0.0000 \\
\hline P14 & 0.32012 & $0.09764 * *$ & 1.53569 & 0.75221 & 2270.75 & 0.0000 & 0.08980 & 0.08408 & 1.53739 & 0.80657 & 3098.32 & 0.0000 \\
\hline $\begin{array}{c}\text { Avg } \\
\text { Rf }\end{array}$ & 0.01724 & Average & $\mathrm{rm}=(\mathrm{Rm}$ & & 0.14 & 72 & Avg Rf & 0.01939 & Average & (Rm-Rf) & 0.00 & \\
\hline
\end{tabular}

$$
* * * \text { Significant at } 99 \%, * * \text { Significant at } 95 \% * \text { significant at } 90
$$

Table 15. Table Showing Consolidated Results for Different Sub Periods by Using 5 Securities

\begin{tabular}{|c|c|c|c|c|c|c|}
\hline \multirow{2}{*}{$\begin{array}{l}\text { Port } \\
\text { folio }\end{array}$} & \multicolumn{6}{|c|}{ Sub Period 7 (2007-2009) } \\
\hline & $\begin{array}{c}\text { Portfolio } \\
\text { return }\end{array}$ & Constant & Beta & $\mathbf{R 2}$ & F Value & P value Beta \\
\hline $\mathrm{P} 1$ & $0.08810 * *$ & $0.07446 * *$ & 0.29498 & 0.30900 & 329.13 & 0.0000 \\
\hline $\mathrm{P} 2$ & 0.08176 & 0.05897 & 0.49271 & 0.49339 & 718.79 & 0.0000 \\
\hline P3 & 0.06897 & 0.04041 & 0.61765 & 0.54659 & 887.28 & 0.0000 \\
\hline $\mathrm{P} 4$ & 0.01236 & -0.02181 & 0.73922 & 0.60759 & 1139.59 & 0.0000 \\
\hline P5 & 0.10275 & 0.06578 & 0.79951 & 0.61307 & 1168.77 & 0.0000 \\
\hline $\mathrm{P} 6$ & 0.06021 & 0.02063 & 0.85599 & 0.74569 & 2158.11 & 0.0000 \\
\hline $\mathrm{P7}$ & 0.08465 & 0.04232 & 0.91536 & 0.70034 & 1720.14 & 0.0000 \\
\hline P8 & 0.07589 & 0.03148 & 0.96031 & 0.80335 & 3006.82 & 0.0000 \\
\hline P9 & 0.15860 & $0.11175 * *$ & 1.01291 & 0.78123 & 2628.33 & 0.0000 \\
\hline P10 & 0.07721 & 0.02722 & 1.08105 & 0.81452 & 3232.01 & 0.0000 \\
\hline P11 & 0.11063 & 0.05557 & 1.19049 & 0.86458 & 4698.93 & 0.0000 \\
\hline P12 & 0.21823 & $0.15881 * * *$ & 1.28490 & 0.76514 & 2397.79 & 0.0000 \\
\hline P13 & 0.11196 & 0.04916 & 1.35803 & 0.85806 & 4449.48 & 0.0000 \\
\hline
\end{tabular}




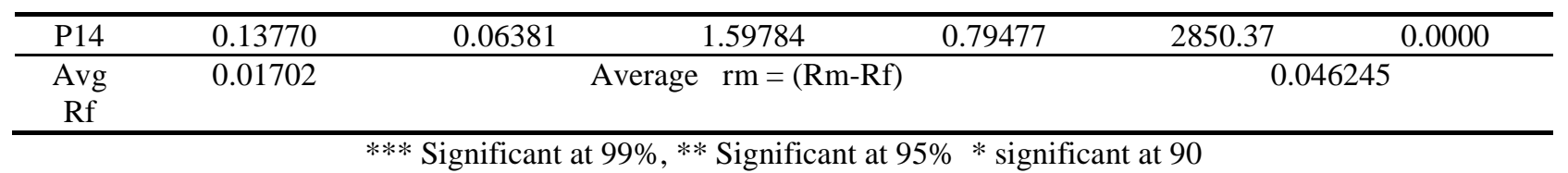

Findings reveals that beta can explain the variation in portfolio return while using equally weighted portfolios and it is found that in most of the cases the return on portfolio increases with increase in beta, but we cannot see this trend in all the portfolios as similar to the previous results

6.7 Test of Non-Linearity

The test for non-linearity shows that in each case the beta square coefficient was insignificantly different from zero, which tells that there exists a linear relationship between expected return and beta. Thus the findings are according to the CAPM hypothesis. But in most of the cases, it is found that the tests in the sub periods were also consistent with the above hypothesis and indicate evidence in supporting the CAPM but did not provide conclusive evidence in favor of CAPM.

Table 16. Consolidated Results for Different Study Periods by Using 5 Securities

\begin{tabular}{|c|c|c|c|c|c|c|c|c|c|}
\hline \multirow[t]{2}{*}{ Coefficient } & \multicolumn{3}{|c|}{ Whole Period (2001-2009) } & \multicolumn{3}{|c|}{ Sub Period 1(2001-2003) } & \multicolumn{3}{|c|}{ Sub Period 2(2002-2004) } \\
\hline & Constant & $\mathrm{t}$-value & $\begin{array}{c}\mathbf{P} \\
\text { value }\end{array}$ & Constant & t- value & $\begin{array}{c}\mathbf{P} \\
\text { value }\end{array}$ & Constant & t- value & $P$ value \\
\hline$\lambda 0$ & 0.0823 & 0.7274 & 0.4822 & 0.0614 & 0.8831 & 0.3961 & 0.11708 & 1.08700 & 0.3005 \\
\hline$\lambda 1$ & 0.1659 & 0.6458 & 0.5316 & 0.3015 & 2.0410 & 0.066 & 0.12597 & 0.51670 & 0.6156 \\
\hline$\lambda 2$ & -0.0332 & -0.2383 & 0.816 & -0.1613 & $-2.266^{* *}$ & 0.0446 & -0.01167 & -0.0906 & 0.9294 \\
\hline
\end{tabular}

** Significant at $95 \%$ level,** Significant at $95 \%$ level

Table 17. Consolidated Results for Different Study Periods by Using 5 Securities

\begin{tabular}{|c|c|c|c|c|c|c|c|c|c|}
\hline \multirow[b]{2}{*}{ Coefficient } & \multicolumn{3}{|c|}{ Sub Period 3(2003-2005) } & \multicolumn{3}{|c|}{ Sub Period 4(2004-2006) } & \multicolumn{3}{|c|}{ Sub Period 5 (2005-2007) } \\
\hline & Constant & t- value & $P$ value & Constant & t- value & $P$ value & Constant & t- value & $P$ value \\
\hline$\lambda 0$ & 0.24430 & $2.8490 * *$ & 0.0158 & 0.450307 & $3.383 * * *$ & 0.0061 & 0.1325 & 0.76954 & 0.4578 \\
\hline$\lambda 2$ & 0.05308 & 0.5643 & 0.5839 & 0.281998 & 2.175 & 0.0524 & 0.0730 & 0.43605 & 0.6713 \\
\hline
\end{tabular}

Note: Some of the coefficients in tables are significant at $90 \%$ level

Table 18. Consolidated Results for Different Study Periods by Using 5 Securities

\begin{tabular}{ccccccc}
\hline \multirow{2}{*}{ coefficient } & \multicolumn{2}{c}{ Sub Period 6 (2006-2008) } & \multicolumn{3}{c}{ Sub Period 7 (2007-2009) } \\
\cline { 2 - 7 } & Constant & t- value & P value & Constant & t- value & P value \\
\hline$\lambda 0$ & 0.1067 & 1.0370 & 0.3222 & 0.0777 & 1.073 & 0.3064 \\
\hline$\lambda 1$ & -0.2344 & -1.0620 & 0.3110 & -0.0457 & -0.2867 & 0.7797 \\
\hline$\lambda 2$ & 0.1637 & 1.4520 & 0.1743 & 0.06414 & 0.7770 & 0.4536 \\
\hline
\end{tabular}

The test for non-linearity for the whole period shows that in each case the beta square coefficient was significantly different from zero, which tells that there exists a linear relationship between expected return and beta. Thus the findings are according to the CAPM hypothesis. Further it is found that the tests in the sub periods were also consistent with the above hypothesis and indicate evidence in supporting the CAPM but did not provide conclusive evidence, or not fully in favor of the CAPM in all the tests. This leads to the conclusion that some of the results is inconsistent with the theory and hence against the CAPM. The test for portfolios based on percentage return with equally weighted portfolios having 5 securities does not give conclusive evidence in support of CAPM. In some periods, the test clearly rejects the CAPM hypothesis and in few periods it partially supports the CAPM hypothesis. Further in some of the sub periods the constants are insignificant and reject the CAPM hypothesis. The study also found that, during the study period most of the portfolios, including the portfolio with lowest beta earned more than 
the average excess market return and the positive constants suggest that the portfolios earned higher return than the CAPM has predicted. The fluctuation in the market seems to influence the return of the portfolios. During the period of recession, some of the portfolios found to report a negative return (during the sub period 2006-2008)

7. Summaries and Conclusion

Investment decision is one of the key areas in finance and the risk return relationship is one of the most discussing facts in investment decisions. This study tested the empirical validity of CAPM, and non-linearity between risk return. The result of the study is mostly in support and favor of the CAPM and is in support Ansari (2000) who suggests that the evidence is not sufficient to drop the use of the model. While comparing the test with ten securities and five securities it is found that the CAPM rejected in more tests when portfolios are formed with 10 securities and it shows almost similar result but there is difference in rejection period. This leads to the conclusion that portfolio combination may have importance in pricing and it should be established with more empirical tests. In short the result reveals that the CAPM not conclusively validated during the study period and this do not means that the data fully reject CAPM. present study reveals that beta can explain the variation in portfolio return while using equally weighted portfolios and it is found that, in most of the cases the return on portfolio increases with increase in beta, but we cannot see this trend in all the portfolios.

References

Andor, G., Ormos, M., \& Szabó, B. (1999). Empirical tests of Capital Asset Pricing Model (CAPM) in the Hungarian capital market. Social and Management Sciences, 7(1), 47-64.

Ansari, V. A. (2000). Capital Asset Pricing Model: Should We Stop Using It?. Vikalpa, 25(1), 55-64.

Banz, R. W. (1981). The relationship between return and market value of common stocks. Journal of financial economics, 9(1), 3-18.

Bark, H. K. K. (1991). Risk, return, and equilibrium in the emerging markets: evidence from the Korean stock market. Journal of Economics and Business, 43(4), 353-362.

Basu, S. (1977). Investment performance of common stocks in relation to their price-earnings ratios: A test of the efficient market hypothesis. The Journal of Finance, 32(3), 663-682.

Bhandari, L. C. (1988). Debt/equity ratio and expected common stock returns: Empirical evidence. The Journal of Finance, 43(2), 507-528.

Chan, L. K., Hamao, Y., \& Lakonishok, J. (1991). Fundamentals and stock returns in Japan. The Journal of Finance, 46(5), 1739-1764.

Chan, Y. C. (1997). Multivariate testing of the capital asset pricing model in the Hong Kong stock market. Applied Financial Economics, 7(3), 311-316.

Fama, E. F., \& French, K. R. (1993). Common risk factors in the returns on stocks and bonds. Journal of financial economics, 33(1), 3-56.

Fan, S. C. (2004). Have we misinterpreted CAPM for 40 years? A theoretical proof. A Theoretical Proof (September 15, 2004),Working Paper Series, http://www.ssrn.com/.

Gibbons, M. R., \& Ferson, W. (1985). Testing asset pricing models with changing expectations and an unobservable market portfolio. Journal of Financial Economics, 14(2), 217-236.

Harris, R. S., Marston, F. C., Mishra, D. R., \& O'Brien, T. J. (2003). Ex ante cost of equity estimates of S\&P 500 firms: the choice between global and domestic CAPM. Financial Management, 51-66.

Jagannathan, R., \& Wang, Z. (1996). The conditional CAPM and the cross-section of expected returns. The Journal of Finance, 51(1), 3-53.

Jensen, M. C., Black, F., \& Scholes, M. S. (1972). The capital asset pricing model: Some empirical tests.

Lintner, J. 1965. The valuation of risk assets and the selection of risky investments in stock portfolios and capital budgets, Review of Economics and Statistics, (47), 13-37.

Madhusoodanan, T. P. (1997). Risk and return: a new look at the Indian stock market. Finance India, 11, $285-304$.

Majumdar, S., Bacon, F,W, 2007, "Multi Factor Pricing Model: An Alternative Approach to CAPM", ASBBS EJournal, Volume 3, No. 1.

Malin, M., \& Veeraraghavan, M. (2004). On the robustness of the Fama and French multifactor model: evidence from France, Germany, and the United Kingdom. International Journal of Business and Economics, 3(2), 155-176.

Manjunatha, T., Mallikarjunappa, T., \& Begum, M. (2007). Capital Asset Pricing Model: Beta and Size Tests. AIMS International Journal of Management, 1(1), 71-87.

Michailidis, G, Tsopoglou, S., Papanastasiou, D. and Mariola, E. (2006)“Testing the Capital Asset Pricing Model (CAPM): The Case of the Emerging Greek Securities Market" International Research Journal of Finance and Economics, Vol.4, PP.78-91.

Mohanty, P.(2002). "Evidence of Size Effect on Indian Stock Returns”, Vikalpa, 27(2), pp.27-37. 
Mossin, J. 1966. Equilibrium in a capital asset market. Econometrica, (34), 768-783.

Pettengill, G. N., Sundaram, S., \& Mathur, I. (1995). The conditional relation between beta and returns. Journal of Financial and quantitative Analysis, 30(01), 101-116.

Rahman, M., Baten, A., \& Alam, A. U. (2006). An empirical testing of capital asset pricing model in Bangladesh. Journal of Applied Sciences, 6(3), 662-667.

Rao, N. and Bhole, L,M., 'Inflation and Equity Returns', Economic andPolitical Weekly, 26 May 1990, pp.m91m96

Roll, R. (1977). A critique of the asset pricing theory's tests Part I: On past and potential testability of the theory. Journal of financial economics, 4(2), 129-176.

Ross, S. A. (1976). The arbitrage theory of capital asset pricing. Journal of economic theory, 13(3), 341-360.

Sehgal, S. (1997). An Empirical Testing of Three parameter Capital Asset Pricing Model in India. Finance India, $11(4), 424-442$.

Sehgal, S. (2003). Common factors in stock returns: the Indian evidence. The ICFAI Journal of Applied Finance, 9(1), 5-16.

Sharpe, W. 1964. Capital asset prices: a theory of market equilibrium under conditions of risk. Journal of Finance , (33),885-901.

Srinivasan, S. (1988). Testing of Capital Asset Pricing Model in Indian Environment. Decision, 15(1), 51-59.

Stattman, D. (1980). Book values and stock returns. The Chicago MBA: A journal of selected papers, 4(1), 25-45.

Vaidyanathan, R. (1995). Capital Asset Pricing Model: The Indian Context. The ICFAI Journal of Applied Finance, l(2), 221-224.

Xu, D., \& Yang, X. (2007). Testing the CAPM Model: A study of the Chinese Stock Market. , Master Thesis Essay. Sweden: UMEA School of Business

Copyrights

Copyright for this article is retained by the author(s), with first publication rights granted to the journal.

This is an open-access article distributed under the terms and conditions of the Creative Commons Attribution license (http://creativecommons.org/licenses/by/4.0/). 